Jurnal Teknik Komputer AMIK BSI

Volume 7, No.2, Juli 2021

P-ISSN 2442-2436, E-ISSN: 2550-0120

Akreditasi Ristekdikti, No: 36/E/KPT/2019 (Sinta 4)

DOI: $10.31294 /$ jtk.v4i2

\title{
Rancang Bangun Sistem Informasi Inventory Stock Barang Berbasis Web
}

\author{
Wahyudin ${ }^{1}$, Sinta Bela ${ }^{2}$ \\ ${ }^{1}$ Universitas Bina Sarana Informatika, Program Studi Teknologi Informasi \\ 1e-mail: Wahyudin.whd@bsi.ac.id \\ ${ }^{2}$ STMIK Nusa Mandiri \\ 2e-mail: sBela7799@gmail.com
}

\begin{tabular}{ccc}
\hline Diterima & Direvisi & Disetujui \\
$08-06-2021$ & $23-06-2021$ & $25-07-2021$ \\
\hline
\end{tabular}

\begin{abstract}
Abstrak - Inventory barang merupakan suatu hal yang penting di sebuah perusahaan, maka dari itu Inventory dapat mengelola stok barang pada gudang yang akan dijual kepada konsumen, Dengan adanya sistem informasi inventory ini, dapat membantu dalam melakukan pencatatan dan pengecekan persediaan sembako. Agen Kianda merupakan sebuah usaha yang bergerak dalam bidang ritel, perusahaan ini membutuhkan suatu sistem informasi inventory untuk membantu pendataan stock barang yang lebih akurat. Oleh karena itu penulis mencoba membuat Skripsi mengenai inventory stock barang di Agen Kianda yang belum terkomputerisasi. Pendataan Stock barang pada Agen Kianda masih menggunakan sistem manual, dengan sistem yang masih manual beresiko terjadinya penumpukan stock barang, untuk itu dengan adanya sistem informasi inventory stock barang ini merupakan solusi yang terbaik untuk permasalahan yang ada, dengan sistem yang terkomputerisasi adapat tercapainya kegiatan yang lebih efektif.
\end{abstract}

Kata Kunci: Inventory, Web, PHP

\begin{abstract}
Inventory goods is an important thing in a company, therefore Inventory can manage the stock of goods in the warehouse that will be sold to consumers, with this Inventory information system, can assist in the recording and checking of food supplies.Kianda Agent is a business engaged in the field of retail, the company needs an inventory information system to help data collection of goods more accurately. Therefore, the author tried to make a thesis on the inventory stock of goods at the Kianda agent that has not been computerized. Stock collection of goods on agent Kianda still use manual system, with the system still manual at risk of buildup of Stock of goods, therefore with the existence of information system of inventory stock of goods is the best solution for the problem, with computerized system that has been achieved more effective activities.
\end{abstract}

Keywords: Inventory, Web, PHP

\section{PENDAHULUAN}

Seiring dengan berkembangnya teknologi di era globalisasi, pada umumnya memudahkan manusia untuk bertukar informasi dengan cepat. Teknologi merupakan alat bantu yang sering dipergunakan dalam aktivitas sehari-hari, Penggunaan teknologi informasi ini memudahkan para pembisnis untuk dapat melakukan aktivitas bisnisnya dan memudahkan untuk bersaing dengan pelaku bisnis lainnya, teknologi informasi ini juga dapat mengubah tata cara kerja menjadi lebih cepat dan sederhana. Semua pekerjaan yang sebelumnya dilakukan dengan manual setelah munculnya teknologi informasi yang kini dapat terselesaikan dalam waktu yang cepat. Teknologi informasi bisa dapat dipergunakan oleh berbagai jenis usaha, yang dimana teknologi informasi ini dapat memberikan banyak sekali kontribusi yang sangat baik dalam sistem informasi di setiap bidang usaha.

Perusahaan yang bergerak dibidang penjualan yang masih menggunakan cara manual, dimana dalam kegiatan operasional sistem persediaan barang masih dicatat menggunakan media kertas. Pemakaian komputer sebagai alat pengolah data dapat dikatakan yang terbaik untuk saat ini, karena dapat meningkatkan kecepatan pekerjaan sehingga mampu menghasilkan keluaran berupa informasi yang akurat serta efisiensi tenaga dan waktu dalam mengolah data. Dengan demikian kemungkinan kesalahan perhitungan dengan cara manual dapat diatasi jika tersedia dukungan suatu sistem yang terkomputerisasi (Sikumbang, 2016).

Dengan berkembangnya semua kemajuan yang ada pada teknologi informasi serta komunikasi ini, persaingan yang ada dalam dunia industri saat ini menjadi sangat ketat, 
meningkatnya jumlah perusahaan semakin banyak yang melakukan strategi maupun usaha untuk mempertahankan bisnisnya. Kesuksesan yang ada pada perusahaan untuk mempertahankan bisnisnya tidak luput dari peranan perusahaan dalam mengelola Inventory ( penyediaan ) pada barang sehingga selalu dapat memenuhi semua permintaan dari konsumen sebaik mungkin. Sebuah perusahaan yang mampu mengendalikan maupun mengelola

semua penyediaanya dengan cepat dan bisa memenuhi semua kebutuhan konsumen tentunya bisa menjaga nama baik bisnisnya di dunia industri pada saat ini. Inventory barang adalah suatu hal yang penting di sebuah perusahaan, maka dari itu Inventory dapat mengelola stok barang pada gudang yang akan dijual kepada konsumen.

Dengan adanya sistem informasi inventory ini, dapat membantu dalam melakukan pencatatan dan pengecekan persediaan sembako pada agen kianda, semua barang-barang yang masuk dan keluar dapat diketahui dengan sangat jelas. (Gustina, Sumbaryadi, \& Nuryanto, 2015)

Agen Kianda yang terletak di jl.Pembangunan 1 Darusalam Kel. Batu sari Kec.Batu Ceper Kota Tanggerang, Agen kianda yang merupakan usaha yang bergerak pada bidang ritel yang mana agen ini menjual berbagai macam sembako untuk keperluan sehari-hari dan juga mendistribusikan barang dagangnya kepada konsumen yang membeli secara eceran maupun grosir, proses pendistribusiannya itu sendiri untuk konsumen yang membeli secara eceran yaitu konsumen datang secara langsung ke agen kianda, sedangkan untuk konsumen yang membeli secara grosiran adalah dengan melakukan pencatatan semua barang yang akan dibeli.

Agen kianda masih melakukan pencatatan secara manual untuk pencatatan stok bahan-bahan sembako maupun pendataan keluar masuk nya bahan-bahan yang ada. Sehingga terkadang terjadi kesalahan pada pencatatan stok yang mengakibatkan menumpuknya bahan sembako yang ada pada agen kianda.

Berdasarkan latar belakang yang ada, maka akan dilakukan penelitian dengan "Sistem Informasi Inventory Stok Barang Pada Agen Kianda Berbasis Web" yang mana akan memudahkan dalam proses penyediaan stok serta pendataan keluar masuknya bahan sembako pada agen kianda. 1 .

\section{METODOLOGI PENELITIAN}

\section{Pengumpulan Data}

Berikut ini teknik pengumpulan data yang digunakan untuk memperoleh data dan informasi. a. Observasi

Pada metode ini penulis melakukan pengamatan secara langsung mengenai semua alur proses yang sedang berjalan pada Agen Kianda agar mendapatkan sebuah informasi secara langsung yang nantinya akan diolah melalui sistem inventory.

\section{b. Wawancara}

Melakukan kegiatan wawancara secara langsung dengan pemilik Agen Kianda yaitu ibu Surya Nova, beserta dengan karyawan yang terlibat.

$$
\text { c. Studi Pustaka }
$$

Studi pustaka yang dilakukan agar dapat membantu penelti, dengan buku, jurnal dan literatur yang mana berkaitan dengan masalah yang akan diselesaikan.

\section{Model Pengembangan Sistem}

Penulis menggunakan metode pengembangan sistem dengan menerapkan metode waterfall.

Metode waterfall atau biasa disebut dengan model model air terjun, model ini juga mengambil kegiatan sebuah proses dasar seperti pengembangan, spesifikasi validasi serta evolusi, setelah itu dipesentasikan sebagai fase yang diproses berbeda. Model proses ini juga sering disebut dengan waterfall atau Classic Life Cycle Model. (Saprudin \& Hermawan, 2019)

\section{a. Analisa Kebutuhan Software}

Proses dalam menganalisa dan pada pengumpulan data semua kebutuhan yang ada pada sistem sesuai dengan informasi unjuk kerja, antar muka dan tingkah laku. Program ini dibangun yang untuk memenuhi semua kebutuhan terhadap fase analisis, perangkat lunak yang dibangun untuk mendukung sistem adalah dengan menggunakan PHP, Subime Text beserta MySQL

\section{b. Desain}

Dalam Membuat desain pada pemrograman pada data-data yang telah didapatkan maupun dimodelkan pada arsitektur sistem inventory pada barang yang berbasis web, penulis menggunakan UML (Unfied Modeling language) sebagai pemodelan sistem, sedangkan untuk desain pada database penulis menggunakan ERD.

\section{c. Code Generation}

Program yang dibuat penulis yaitu menggunakan pemrograman yang terstuktur, Bahasa yang digunakan untuk membuat program ini ialah dengan MySQL dan PHP sebagai database.

\section{d. Testing}

Proses ini merupakan Proses sebuah testing pada sistem yang telah kita buat apakah bisa berjalan dengan baik atau tidak. Proses testing yang penulis pergunakan ialah proses black box.

\section{e. Support}

Pada tahapan support maupun pemeliharaan pada sistem yang telah dibuat harus sesering mungkin melakukan update dan pembenahan untuk sistem yang belum optimal. 


\section{HASIL DAN PEMBAHASAN}

\section{Proses Sistem Berjalan}

Agen kianda membuat daftar pemesanan bahan pokok sembako kepada supplier melalui chat whatsapp, lalu supplier akan menerima dan menyiapkan barang yang dipesan, apabila barang pesanan kosong atau tidak tersedia maka pengiriman akan ditunda sampai barang tersedia. Akan tetapi jika barang tersedia maka supplier akan langsung melakukan pengiriman pada agen. Ketika barang sudah sampai, pihak agen akan menerima barang serta langsung mengecek barang, tetapi jika barang yang datang mengalami rijeck maka akan langsung di retur kepada supplier, dan jika barang dalam keadaan bagus atau sesuai maka supplier akan langsung memberikan Nota pembayaran kepada Agen untuk melakukan transaksi pembayaran. Customer melakukan pembelian secara langsung dengan membawa daftar belanja, kemudian daftar belanjaan tersebut di serahkan ke pegawai agen.selanjutnya pegawai agen akan menyiapkan barang yang di pesan oleh customer, setelah itu customer mengecek barang yang sudah dipesan, jika sudah lengkap pegawai agen akan menyerahkan barang tersebut ke kasir. Selanjutnya kasir akan membuat nota dan menyerahkan nota pembayaran kepada customer, setelah itu customer akan melakukan pembayaran

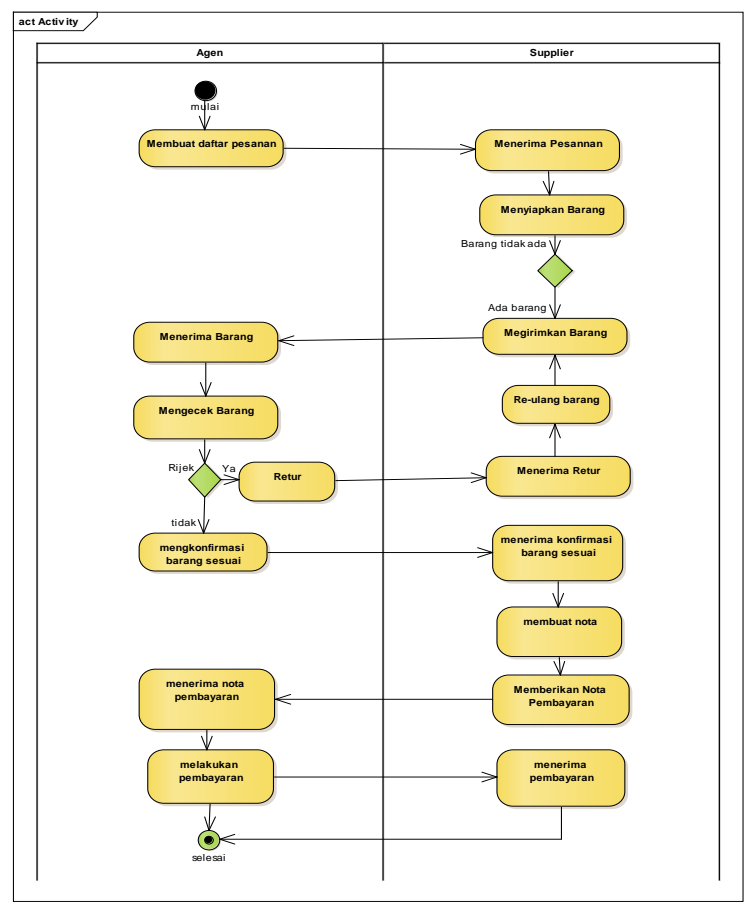

Sumber : Wahyudin \& Bela (2021)

Gambar I. Activity Diagram Sistem Pemasukan Barang.

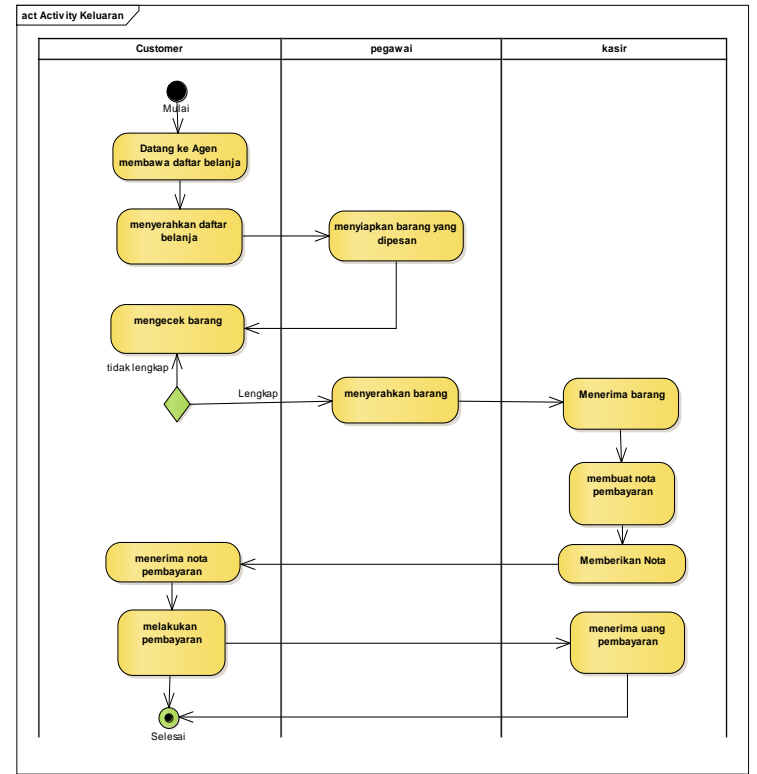

Sumber : Wahyudin \& Bela (2021)

Gambar II. Activity Diagram Sistem Pengeluaran Barang.

\section{Rancangan Sistem Dan Program Usulan}

\section{A. Tahapan Analisa}

Dalam sistem informasi inventory ini, dibagi menjadi 3 hak akses, yaitu admin, pegawai dan kasir, admin adalah hak akses yang paling tinggi yang dimana admin dapat mengakses semua fitur yang ada. Setelah itu pegawai hanya diberikan hak akses untuk dapat melihat stok barang. Sedangkan untuk hak akses transaksi diberikan kepada kasir untuk dapat menjalankan proses transaksi serta mengecek barang masuk dan keluar. Untuk lebih jelasnya, akan dijelaskan mengenai spesifikasi kebutuhan (system requirement), dari sistem inventory barang berikut ini

Akses Admin :

A.1. Admin dapat melakukan login

A.2. Admin dapat mengatur data master

A.3. Admin dapat pesan barang

A.4. Admin dapat input barang masuk

A.5. Admin dapat melihat stok info

A.6. Admin dapat melihat history transaksi

A.7. Admin dapat memperbaharui password untuk login

A.8. Admin juga dapat melakukan logout

Akses Pegawai :

B.1. Pegawai dapat melakukan login

B.2. Pegawai dapat melihat stok barang

B.3. Pegawai dapat mengubah password

Akses Kasir :

C.1. kasir dapat melakukan login

C.2. Kasir dapat melakukan pengecekan stok barang

C.3. Kasir dapat melakukan transaksi barang keluar 


\section{C.4. Kasir dapat merubah password}

\section{B. Use Case Diagram}

Use Case diagram memperlihatkan suatu interaksi antara antara use case, dan pegawai. Diagram ini juga menjabarkan model yang lengkap mengenai apa saja yang dilakukan dan juga siapa saja yang berperan didalam maupun diluar sistem.

1. Use Case Diagram Hak Akses Admin

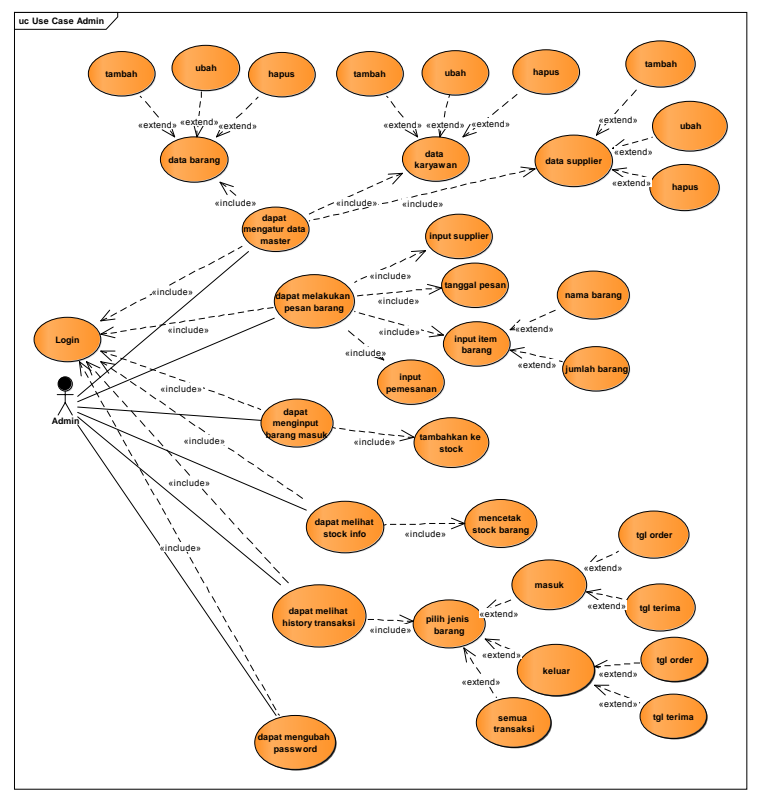

Sumber : Wahyudin \& Bela (2021)

Gambar III. Use Case Diagram Hak Akses Admin

2. Use Case Diagram Hak Akses Pegawai

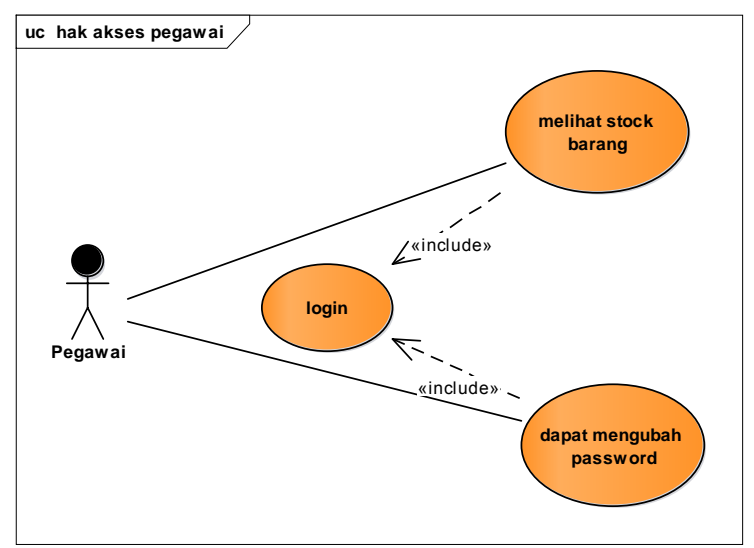

Sumber : Wahyudin \& Bela (2021)

Gambar IV. Use Case Diagram Hak Akses Pegawai

3. Use Case Diagram Hak Akses Kasir

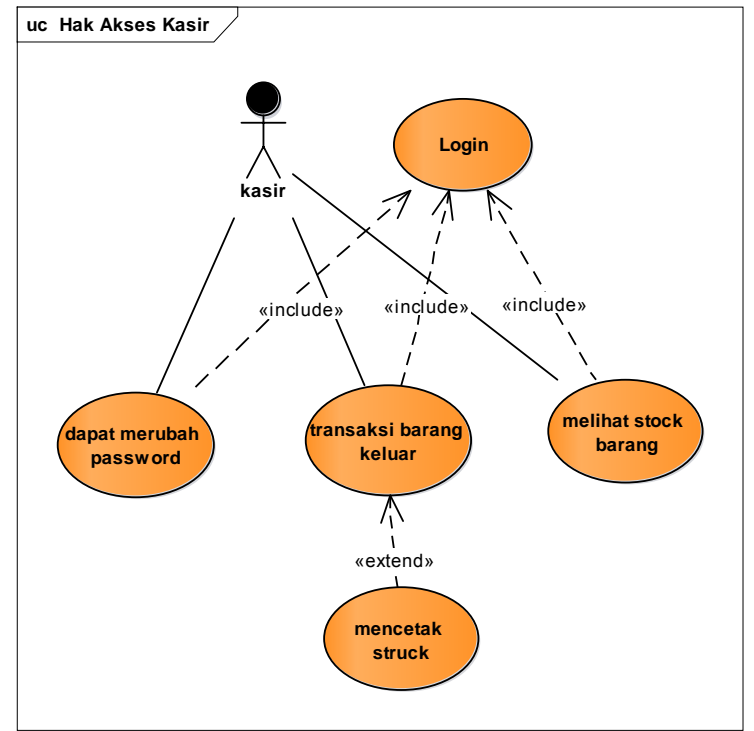

Sumber : Wahyudin \& Bela (2021)

Gambar V. Use Case Diagram Hak Akses Kasir

C. Activity Diagram

1. Activity Diagram Mengatur Data Master

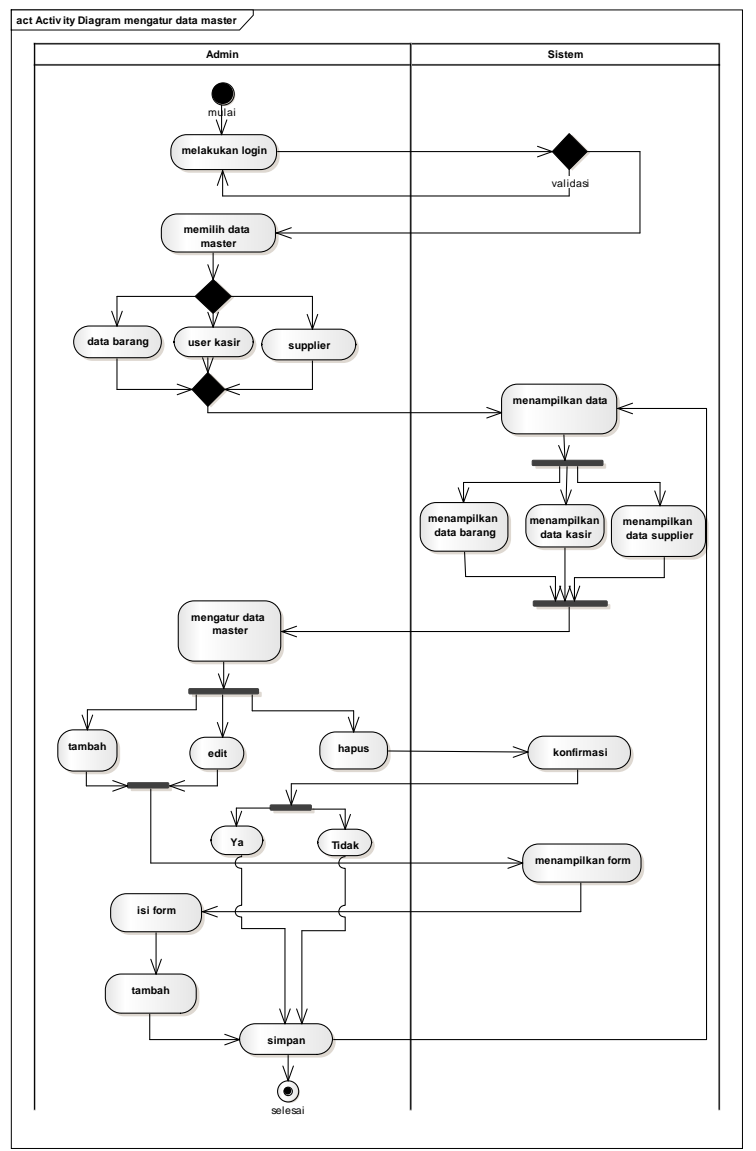

Sumber : Wahyudin \& Bela (2021)

Gambar VI. Activity Diagram Mengatur Data Master 
2. Activity Diagram Pesan Barang

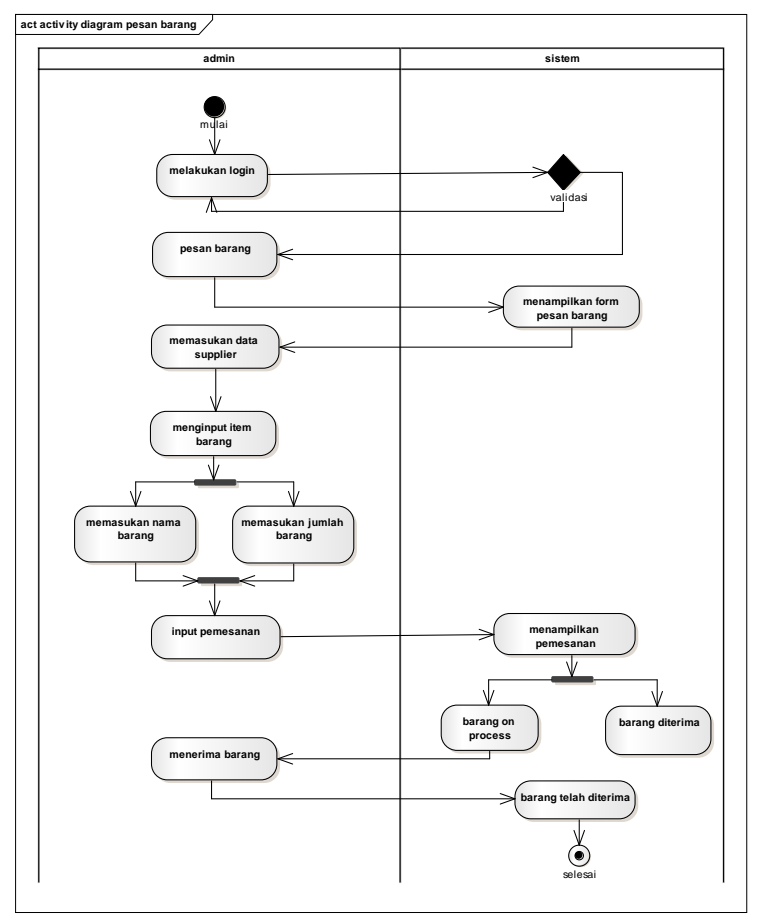

Sumber : Wahyudin \& Bela (2021)

Gambar VII. Activity Diagram Pesan Barang

3. Activity Diagram Barang Masuk

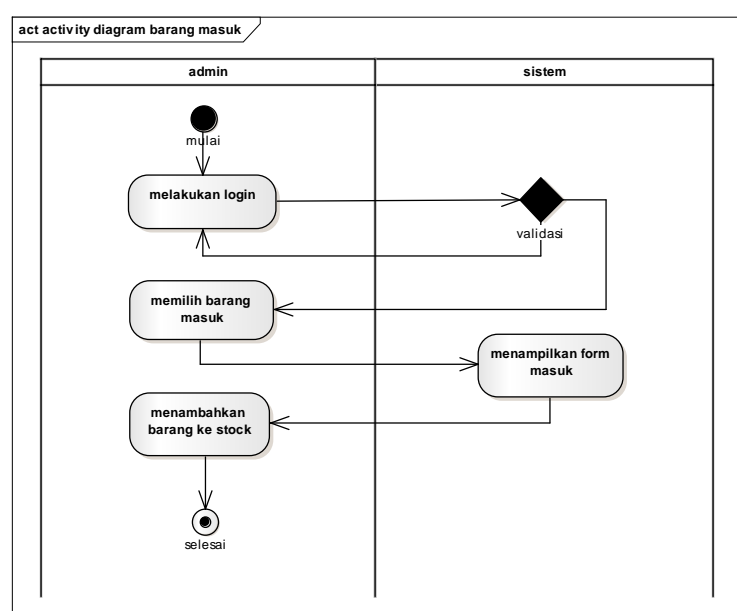

Sumber : Wahyudin \& Bela (2021)

Gambar VIII. Activity Diagram Barang Masuk

4. Activity Diagram Stock info

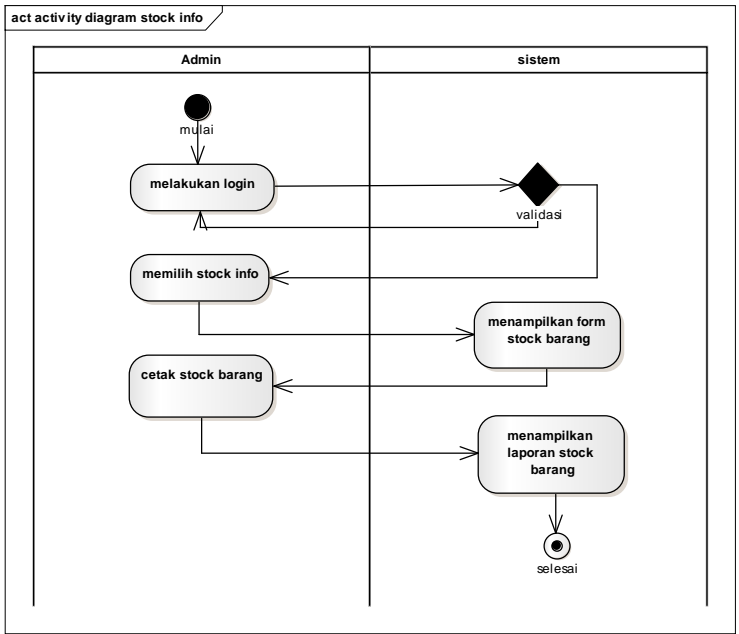

Sumber : Wahyudin \& Bela (2021)

Gambar XI. Activity Diagram Stock info

5. Activity Diagram Transaksi Barang Keluar

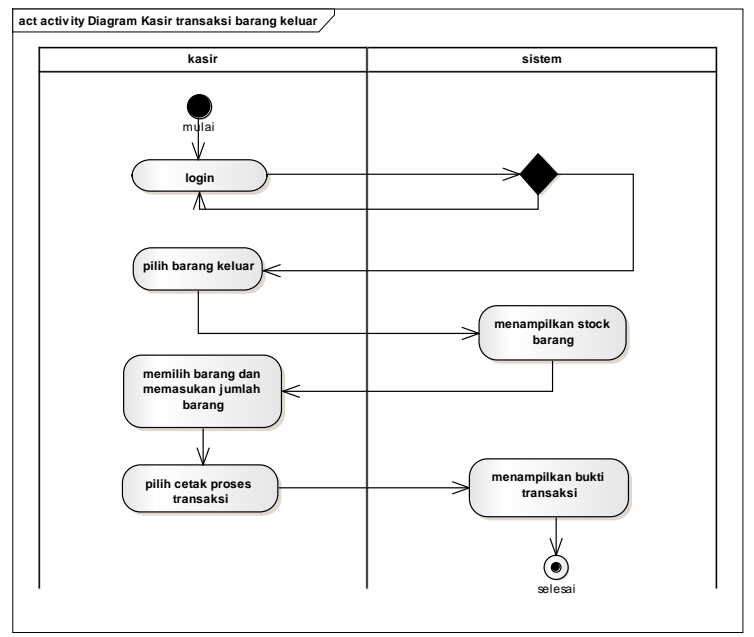

Sumber : Wahyudin \& Bela (2021)

Gambar X. Activity Diagram Transaksi Barang Keluar

6. Activity Diagram Mengubah password

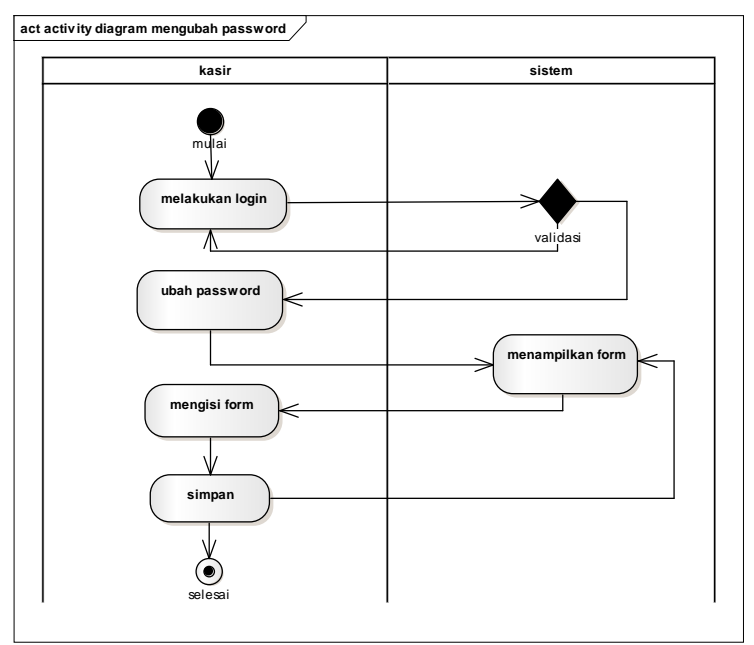

Sumber : Wahyudin \& Bela (2021)

Gambar XI. Activity Diagram Mengubah Password 


\section{Entity Relastionship Diagram (ERD)}

ERD yang ada dalam sistem informasi inventory barang berbasis web pada Agen Kianda seperti berikut :

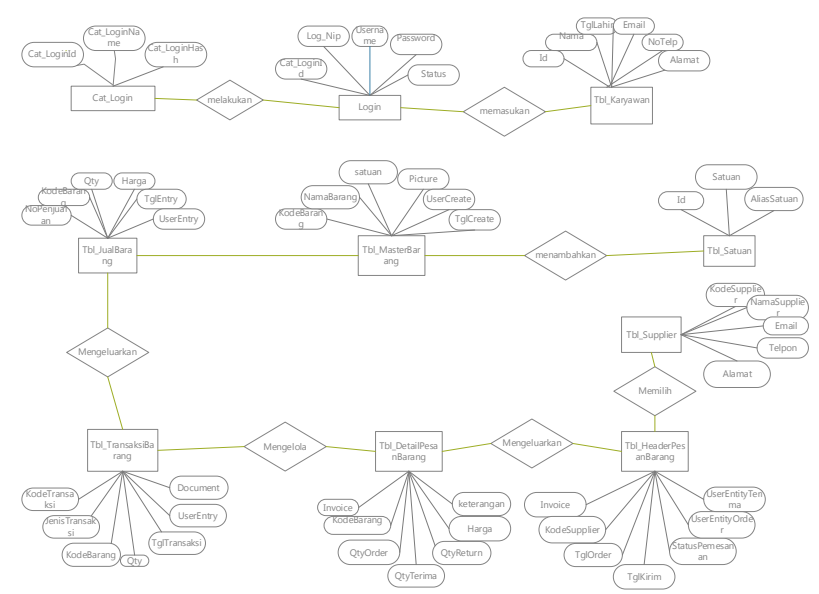

Sumber : Wahyudin \& Bela (2021)

Gambar XII. Entity Relastionship Diagram (ERD)

\section{E. LRS ( Logical Record Structure)}

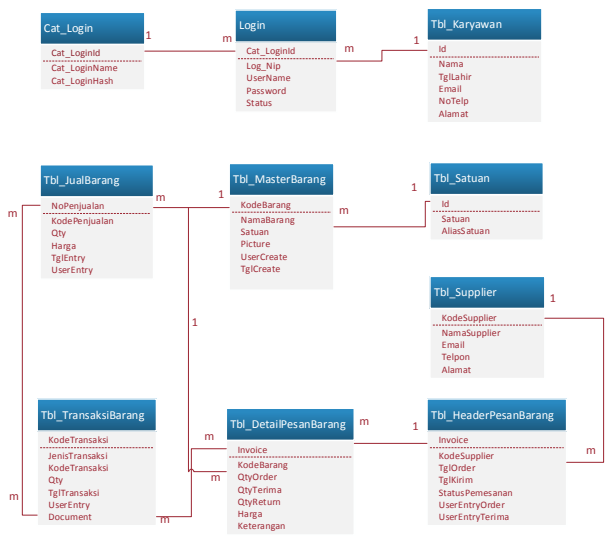

Sumber : Wahyudin \& Bela (2021)

Gambar XIII. LRS ( Logical Record Structure)

\section{Rancangan User Interface}

A. Tampilan Login

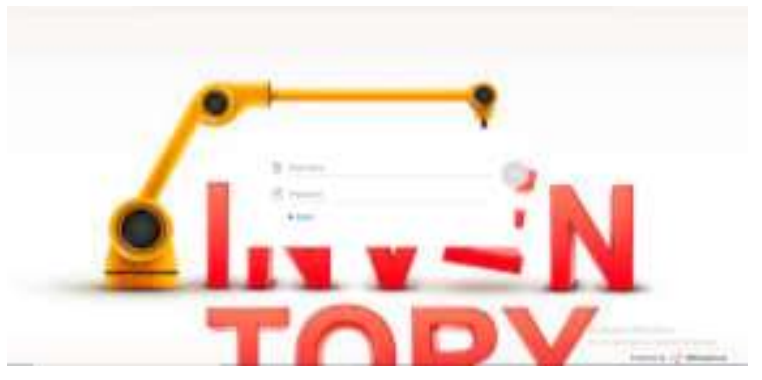

Sumber : Wahyudin \& Bela (2021)

Gambar XIV. Tampilan Halaman Login

B. Tampilan Beranda

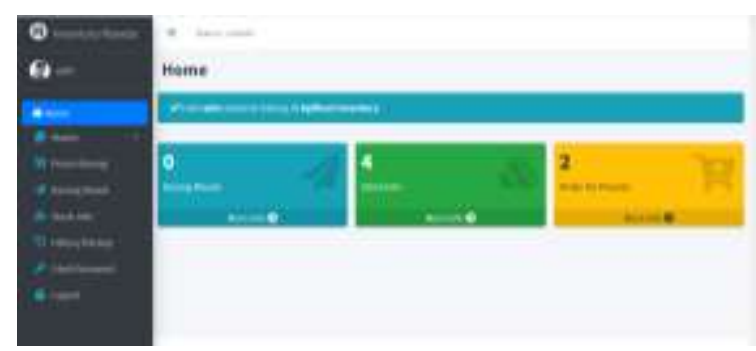

Sumber : Wahyudin \& Bela (2021)

Gambar XV. Tampilan Halaman Beranda

C. Tampilan Data Barang

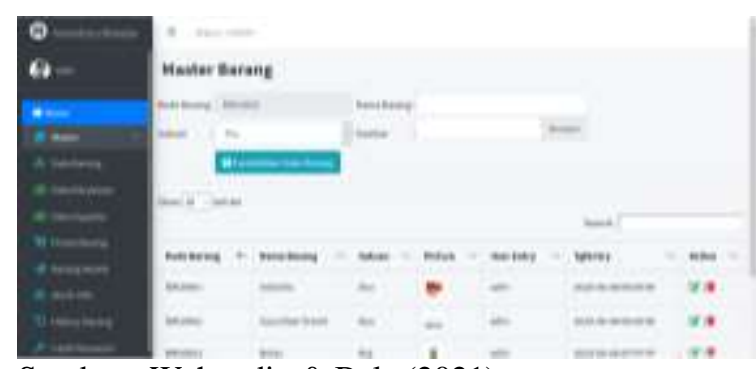

Sumber : Wahyudin \& Bela (2021)

Gambar XVI. Tampilan Data Beranda

D. Tampilan Data Karyawan

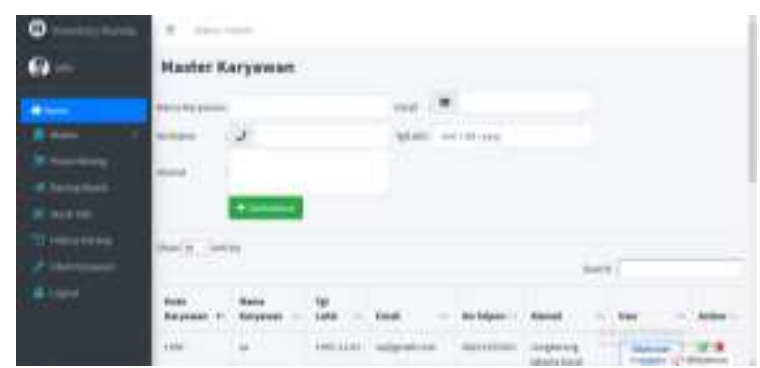

Sumber : Wahyudin \& Bela (2021)

Gambar XVII. Tampilan Data Karyawan

E. Tampilan Data Supplier

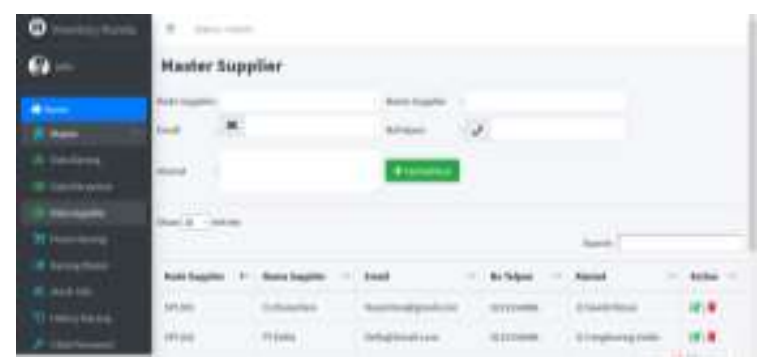

Sumber : Wahyudin \& Bela (2021)

Gambar XVIII. Tampilan Data Suppllier 
F. Tampilan Pesan Barang

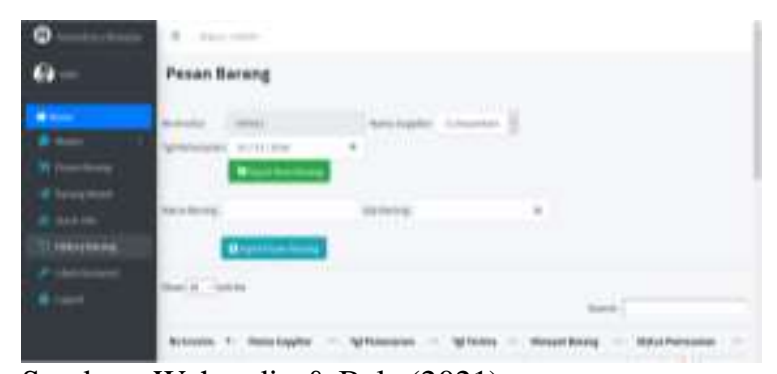

Sumber : Wahyudin \& Bela (2021)

Gambar XIX. Tampilan Data Pesan Barang

G. Tampilan Stock Info

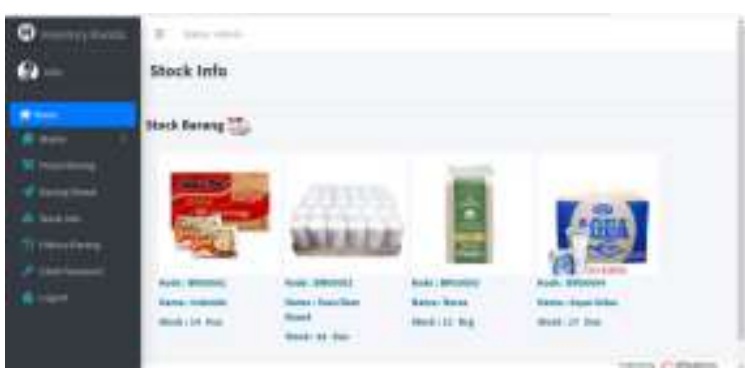

Sumber : Wahyudin \& Bela (2021)

Gambar XX. Tampilan Stock Info

H. Tampilan Transaksi Barang Keluar

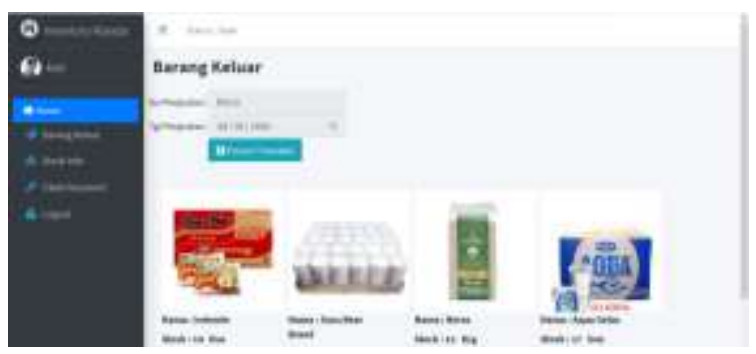

Sumber : Sinta \& Wahyudin (2020)

Gambar XXIII. Tampilan Transaksi Barang Keluar

\section{KESIMPULAN}

Berdasarkan dari hasil penelitian yang dilakukan maka dapat disimpulkan :

1. Pada sistem informasi inventory berbasis web ini dapat mempermudah pemilik Agen beserta pegawainya untuk mengelola stok barang.

2. Desain pada sistem informasi inventory berbasis web ini mudah untuk dipahami.

3. Dengan menggunakan sistem informasi inventory ini dapat mengurangi kesalahan pada saat meng-input barang masuk dan keluar.

4. Mempermudah proses perhitungan pada stok barang

5. Dalam sistem ini penulis menggunakan 3 hak akses yang diberikan kepada Admin, Pramuniga/pegawai, dan Kasir.

\section{REFERENSI}

Anggraeni, E. Y., \& Irviani, R. (2004). Sistem Informasi Manajemen. Yugyakarta: Andi Publisher.

Gustina, D., Sumbaryadi, A., \& Nuryanto, A. (2015). RANCANG BANGUN SISTEM INFORMASI MANAJEMEN PERSEDIAAN OBAT PADA APOTEK KIMIA FARMA. SNT (pp. 1-7). Jakarta: BSI.

Ichsan. (2013, November). Sistem Pendukung Keputusan Pemilihan Penerima Beasiswa Mahasiswa Kurang Mampu Pada STMIK BUDIDARMA Medan Menerapkan Metode Profile Matching. Kursor, 5(1), 2. Retrieved April 14, 2016, from http://pelitainformatika.com/berkas/jurnal/1.\%20TM\% 20Syahru.pdf

Saprudin, S., \& Hermawan, A. (2019). Perancangan Sistem Inventory menggunakan Metode Waterfall pada PT. Lestari Busana Anggun Mahkota. PROSIDING SEMINAR INFORMATIKA DAN SISTEM INFORMASI. Tangerang Selatan: Unpam. Sikumbang, E. D. (2016). SISTEM INFORMASI PERSEDIAAN BARANG BERBASIS WEBSITE MENGGUNAKAN METODE WATERFALL DENGAN KONSEP PEMROGRAMAN TERSTRUKTUR. SNIPTEK. Jakarta: BSI. 